\title{
AYURLOG
}

http://www.ayurlog.com

April- June: 2021 | Volume: $09^{\text {th }}$ | Issue: $2^{\text {nd }}$

ISSN: $2320-7329$

\section{Naadi Pareeksha: a scope to new era}

\section{Mayuri Gujrathi*1, Amit Gujrathi $^{2}$, Sunil Khandare ${ }^{3}$, K. K. Upadhay ${ }^{4}$}

1. MD. (Scholar)

2. MD. Ph. D. Scholar

3. HOD, Professor Dept of Rognidan

4. Professor of Kayachikitsa

Parul Institute of Ayurveda, Vadodara, Maharashtra, India

*Corresponding author: dramitgujrathi555@gmail.com

\section{Abstract:}

Nadi Pariksha is the ancient ayurvedic technique of diagnosis through the pulse. It can accurately diagnose physical, mental and emotional imbalances as well as diseases. It is a non - invasive science that enables to reach the root cause of health issues and not just address the symptoms. Nadi Pariksha understands the vibratory frequency of the pulse at various levels on the Radial artery. Subtle vibrations are read at seven different levels vertically downward that help in ascertaining various functions in the body. The pulse, when examined, reveals both physical \& mental characteristics of the patient. This is interpreted in the form of symptoms along with their prognosis, which helps in understanding the cause. Thus, Nadi Pariksha forms the basis for addressing any ailment in an individual. Additionally, it is also the scientific tool that enables an individual to secure their personalized wellness regimes that range from therapeutic massages, personalized diet, exercise programmes, rigorous detoxification and lifestyle transforming experiences.

Keywords: Nadi Pariksha, pulse, chanchalta, vakragatinadi, sarpgati, jalokagati, Mandukgati-pitta

\section{Introduction:}

Nadi Pariksha is an Ayurvedic tool of diagnosis practiced from long back. Nadi Pariksha is the science of observing the pulse from a perspective of diagnosis of the human body, mind and the sub-conscious. It is commonly known as pulse diagnosis. Nadi Pariksha is done to analyse and estimate the quantity of Tridosha in the body. Tridosha, i.e Vata, Pitta and Kapha are considered as the fundamental elements of health. A balance between these three is considered as Prakriti or healthy status and any imbalance in these three is considered as Vikriti or ill health. As per ancient Ayurvedic text, Nadi can be examined at various places but commonly it is examined at the wrist of the 
person. Conventionally it is examined at right wrist of the males and left wrist of the females. Ideally it should be examined in the early morning and on empty stomach. Dosha usually stay at their own place, i.e. Ashrayasthana and come in the body hollows to do their function. Some of the Dosha are utilized during this process. After the process is over, the remaining Dosha goes back to their original place.

CONCEPT OF NADI Nadi is also known as sphura, sira, veena, sphurani, hansi, dhamani, jivsakshi, jivitadnya are sanskrita synonyms of nadi, as well as pulse in English, these synonyms show functional activity of Nadi, i.e. Spura (nerve), Dhamani (artery), Sira (vein) Rasayani (lymphatic vessels) snayu (ligament). It indicates nadi is a channel existing within the body in the form of blood vessels. Nadi is a channel existing within the body in the form of blood vessels.

NADI PARIKSHA:

Pulse diagnosis was initially identified in the books of Sharangdhar Samhita in the 13th century highlighting the correlation between Nadi and Tridosha. Later, in the 16th century it was again mentioned in 'Bhavprakash' scripted by Shri Bhav Mishrji.

Aims_and_Objects:

To learn the art of Nadi Parikshan.

\section{Materials and Methods:}

Different Ayurveda texts, journals, research papers,

articles are referred to study the conceptual understanding of nadi, its clinical significance and its

usefulness in manifestation and sequelae of the diseases.

\section{Synonym of nadi}

Nadi, dhamani, dharani, dhara, tantuki, snayu,

jeevangyana, hansi.

\section{Nadi location}

Vata, pitta and kapha nadi lies respectively under tarjini

(index finger), madhyama (middle finger) and anamika

(ring finger) of examining vaidya (physician).

\section{Contraindications for Nadi Pariksha}

Nadi Pariksha (pulse examination) should not be

examined in following conditions-

Just after taking bath

Just after taking food

After internal and external anointing therapy

(snehavagahana)

E During hunger

$\square$ During thirst

$\square$ During sleep or just after awakening

Observation: Key Considerations for Accurate Diagnosis Best time for examining the pulse: It is clearly mentioned by all the rishis and vaidyas that the pulsation of pulse varies from time to time and day to day. Kapha pulse is predominant in morning time, pitta dosha is predominant during midday and the vata pulse can be observed in late afternoon and evening. Modern sciences have not yet been able to explain the phenomenon of variation of pulse during different times. Ayurvedic science explains the phenomenon related to the planetary 
action and the effect of moon and sun that has a major control over the changing of rhythmicity of the pulse. Critical rule to adhere prior to pulse diagnosis: For precise diagnosis, it is recommended that the diagnosis be done on empty stomach, early in the morning or three hours after food. The reason behind this principle is because, after food metabolism process begins, the diagnosis process gets distorted. Examine the patient as a whole: A physician must be aware about the physical condition of the patient and must be very attentive to note the general conduct and habits of the patient, facial expression, the reaction toward the climatic conditions, appetite, strength, nature of sleep, breathing pattern, history of ailments and so on. All these facts should also be discussed by the patient so as to confirm the diagnosis made through pulse. Method of examining the pulse: The hand of the patient should be free and slightly flexed at the forearm, so that the left hand of the physician, the 3 fingers of the right hand, namely the index finger, the middle finger and the ring finger of the physician gently touches the skin over the radial artery. The index finger is comfortably placed nearest the thumb and the other two fingers are placed next to it (thumb should not be extended too far nor too much fixed). Usage of three fingers in examining the pulse: It has been observed that it becomes much easier to evaluate a pulse of a person with three fingers than by one. It has been now converted into a rule that vata is established by the tip of the index finger of right-hand, placed on the radial artery next to the root of the thumb of the right hand of the patient, pitta pulse studied by the touch of the tip of middle finger placed next to it and that the kapha pulse by touch of the tip of the ring finger placed next to the middle finger on the artery. Ayurveda supports health without disturbing the natural intelligence of the body. Ayurvedic treatments and techniques have no side effects. As a result, people around the world are now turning towards this ancient science to help them restore and maintain optimal health.

\section{RELATION BETWEEN DOSHA AND NADI}

It is appropriate pressure at various levels of touch of three fingers, ie. each finger feels different pressure due to doshaprabalyata, as acharya explains it in various upamas for identifying gati of doshas or prabalya of doshas:

Sarpagati-Vata Dosha: Vataprabaldosha having characteristic nature of chanchalta, or vakragatinadi, so it represents by sarpgati (serpentine movement) or jalokagati (leach movement).Mandukgati-pitta Dosha: Pitta prabal dosha having characteristic nature of Udreka and

chapel or jumping nature, so it represents Mandukagati (frog) or kakgati (crow), i.e. frog like jumping movement of pulse felt to finger.

Hansagati-Kapha Dosha: Kapha prabaldosha having characteristic nature of sthira, i.e. Hansagati, or paravatgati, i.e. Hansa (regular) walking like movement of pulse felt to finger.

NADI BALA IN MODERN MEDICINE Nadi Pariksha (pulse examination) should be done by rate, rhythm, volume, character; all these are explained in ayurveda as bala of nadi or power of the pulsation. Gati of Nadi 
is directly proportional to doshaprablyata in body. 1. 2.

Gurunadi: Where volume of blood is full or doshas are powerful. Laghunadi: Where volume is disturbed due to any etiology of diseases or doshas are

weak as per acharyas, laghu nadi found in Jwara, dhamnipratichay (high blood pressure), vrikkaroga (renal diseases), vishvikara (toxicity), krodha (anger), yakrutroga (liver disease).

\section{Conclusion:}

Nadi Pariksha has been said as one of the Ashta Sthana Pariksha. This system of examination cannot be practiced easily because of non-availability of detail description about Nadi Pariksha in Ayurvedic literature and lack of practice in the field of science. Nadi Pariksha is an easy tool to arrive at the faster diagnosis like pulse examination in other systems of medicine. In modern era of information and technology, we the scholars of Ayurveda have to use knowledge of Nadi which depends on the subjective knowledge and experience of the physician to objective parameters by the tool of modern science, so that the knowledge of Nadi reaches its height.

\section{References:}

1. Bhelasamhita. Chikitsasthan $8 / 2-5$.

2. Sharma PV. English Translation of Charak Samhita. Choukhamba Orientalia; 1981

3. Murthy KRS. Sushrutasamhita (700 BC). Varanasi: Choukhamba Orientalia; 2005.

4. Yadavji Trikamji, Nandakishor Sharma, Bhanumati. on Sushruta Samhita. Sutrasthana. Varanasi: Krishandas Academy; Reprint 2001.

5. Abhaykatyayan. Nadi Pariksha. ravnkutnaidaniktika. Chukhamba SurbharatiPrakashan; 2014; 14p.

6. Dr.Bramhanand Tripathi. Sharangdhar samhita, purvkhand/adhay-3, page no 27, Varanasi: Choukhamba Surabharti prakashan; 2015.

7. Maiskar VB. Nadi Vivechan. Madhavi Publication; 2009.

8. Dt. Upadhyay GP. Nadi Pariksha Vigyan. Varanasi: Choukhamba SurbartiPublication;2009.

\section{Cite this article:}

Gujrathi, M. (2021). "Naadi Pareeksha: a scope to new era.". Ayurlog: National Journal of Research in Ayurved Science, 9(02). https://doi.org/10.52482/ayurlog.v9i02.842 